\title{
慢性関節リウマチにおける腰椎レ線変化の検討
}

\author{
整形外科前原病院 \\ 中川雅裕・前原東洋 \\ 小桜 秀一郎・福 田 稔 朗 \\ 鹿児島大学整形外科

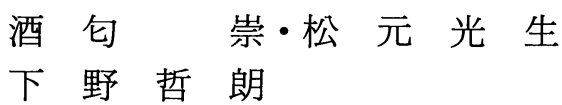

\section{Radiological Study of the Lumbar Spine in the Rheumatoid Arthritis}

by

Masahiro Nakagawa, Toyo Maehara, Shuichiro Kozakura and Toshiro Fukuda

Maehara Orthopedic Hospital, Kobayashi

Takashi Sakou, Kosei Matsumoto and Tetsuro Shimono

Department of Orthopedic Surgery, Faculty of Medicine, Kagoshima University

Rheumatoid involvement of the cervical spine is considered relatively frequent, but there are relatively few references in the literature about the involvement of the thoracic and lumbar spine in the course of rheumatoid arthritis. Radiological Study of the lumbar spine in 68 patients with rheumatoid arthritis showed that :

1. Osteoporosis was seen in 47 patients (69.1\%) and compression fractures in 18 patients (26.5 $\%)$.

2. Osteoporosis and compression fractures were frequent in the RA patient who was older than 60-year-old female and more than Class 2 in Stage III and IV.

3. Incomplete paralysis occurred in 4 cases of compression fractures and one of them seemed related to rheumatoid involvement.

\section{は じめに}

慢性関節リウマチ（以下 RA）において環軸椎亜脱臼 に代表される上位頸椎の変化はよく知られているが, 胸腰椎に関する報告は比較的少ない. 今回われわれは RA 患者の腰椎レ線変化と, 年令, 罹病期間, Stage, Class 等について検討したので若干の文献的考察を加 えて報告する。

\section{対象および方法}

対象は当院で治療した RA 患者 68 例(男性 4 例, 女 性 64 例) で，全例 Definite RA 以上である。年令は 16 才から 86 才で平均 61.5 才, 罹病期間は 6 力月から 59 年, 平均 12 年 4 力月であった. Stage I, II, III, IV はそれぞれ 14 例， 11 例，20 例，23 例であり，Class 1，2，3，4 はそれぞれ，22 例，25 例，17 例，4 例で あった。これらの症例について, 腰椎単純レ線にて, 骨の萎縮度, 圧迫骨折，椎間板の狭小化，椎体の过り， 
椎体縁の Erosionについて検討した。また，骨粗鬆 症，圧迫骨折については上記因子との関連について検 討を加えた，尚，脊椎骨粗鬆の程度は慈大式分類に基 づき分類した。

\section{結果}

骨粗鬆症は 47 例（69.1\%）にみられ，I 度：22 例， II 度：21 例，III度：4 例であった。圧迫骨折は 18 例 (26.5\%) にみられ，L 1 に 10 例と最も多く，いわゆ る退行性骨粗鬆症における骨折部位の分布と類似して いた.この 18 例中 4 例に下肢不全麻痺がみられた. 椎 間腔の狭小化は 22 例 (32.4\%) 38 椎間にみられた。こ のうち RAに多いとされる骨棘を伴わない椎間腔の 狭小化は 5 例 $(7.4 \%)$ であった，椎体の过りは 17 例 （25\%）18 椎間に見られた。椎体縁の Erosion は，5

表 1 腰椎レ線変化

\begin{tabular}{lll}
\hline 骨粗鬆症：47例 (69.1\%) & I 度 & 22 例 \\
& II 度 & 21 例 \\
圧迫骨折 : 18例 $(26.5 \%)$ & III 度 & 4 例 \\
& $\mathrm{L}_{1}$ & 10 例 \\
& $\mathrm{L}_{2}$ & 6 例 \\
& $\mathrm{L}_{3}$ & 6 例 \\
& $\mathrm{L}_{4}$ & 5 例 \\
& $\mathrm{L}_{5}$ & 5 例
\end{tabular}

椎間腔の狭小化：22例（32.4\%）38椎間 椎体の过り：17例 $(25.0 \%) 18$ 椎間 前方沪り 5 椎間 後方过り 9 椎間 側方沪り 4 椎間 椎体縁の Erosion： 5 例 $(7.4 \%) 9$ 椎体

$(\mathrm{N}=68)$

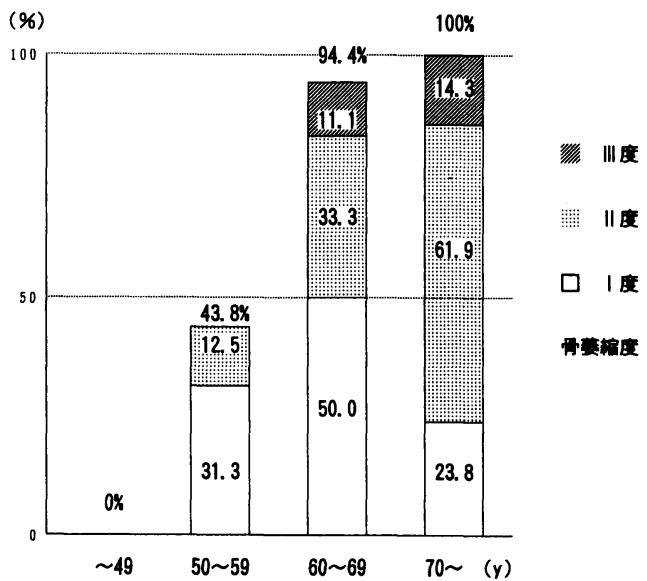

図 $1 ： \mathrm{RA}$ 患者の脊椎骨粗鬆症の年令別発生頻度
例（7.4\%）9椎体にみられた（表 1)

女性 64 例について春椎骨粗鬆症の発生を年令別に みると 49 才以下では $0 \%$ ，50才代では $43.8 \% ， 60$ 才 代で $94.4 \%$ ，70 才以上では 100\%と高令になるにつれ て高頻度となった.また加令とともにII度III度の割合 が高くなる傾向にあった（図 1 ).

Stage 別に発生頻度をみると Stage I, II, III, IV はそれぞれ $53.8 \% ， 45.5 \% ， 73.7 \% ， 85.6 \%$ とtage III, IV に高率にみられ, Class 別では Class 1，2， 3，4 でそれぞれ 50.0\%，80.8\%，73.3\%，100\%と Class 2 以上で高い傾向にあった. 次に年令および骨粗 鬆症と脊椎圧迫骨折との関係をみると, 骨粗鬆症 44 例 中 17 例 $(38.6 \%)$ に圧迫骨折をみとめ, 60 才以上で骨 萎縮度 II 度 III 度者 24 例中圧迫骨折を認めたものは 16 例（66.7\%）でIII度の者には全例圧迫骨折を認めた（図 2 ） Stage おょびClassと圧迫骨折との関係をみると Stage III，IVで Class 2 以上の者が多い傾向にあった (闵 3 ).

Stage I , Class 1 で圧迫骨折の症例は, 86 才の高令者 で外傷によるものである。罹病期間および骨粗鬆症と 圧迫骨折との間には有意な関係は認めなかった。

\begin{tabular}{|c|c|c|c|c|}
\hline III $E=$ & & & $\bullet$ & $\bullet \bullet \bullet$ \\
\hline 川度 & & ০০ & ○) & 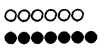 \\
\hline I BE & & 00000 & 000000000 & 0000 \\
\hline$(-)$ & 000000000 & 000000000 & 0 & \\
\hline $\begin{array}{r}\text { Osteoporosis } \\
\text { Noe }\end{array}$ & $\sim 49$ & $50 \sim 59$ & $B 0 \sim 89$ & $70 \sim$ \\
\hline
\end{tabular}

図 2 : 脊椎圧迫骨折と年令および骨粗鬆症との関係 $(\mathrm{N}=64)$

\begin{tabular}{|c|c|c|c|c|}
\hline IV & & $\begin{array}{l}000000 \\
0\end{array}$ & $\begin{array}{l}0,0000 \\
\bullet \bullet \bullet \bullet \bullet \bullet\end{array}$ & 0 \\
\hline III & ০০০ & $\begin{array}{l}0000 \\
\bullet \bullet \bullet \bullet \bullet\end{array}$ & 0000 & $\bullet$ \\
\hline 11 & 00000 & ం০ం০ంீ & & \\
\hline 1 & $\begin{array}{l}000000000 \\
0 \\
\bullet\end{array}$ & $\infty$ & & \\
\hline $\begin{array}{l}\text { Stago } \\
\\
\text { Class }\end{array}$ & 1 & 2 & 3 & 4 \\
\hline
\end{tabular}

図 3 : 脊椎圧迫骨折と Stage およびClass との関係 $(\mathrm{N}=64)$ 


\section{考}

察

RA における胸腰椎病変に関する報告は 1952 年, Baggenstoss $^{1)}$ が Th 12, L 3 椎体圧迫骨折にリウマチ 結節の存在を証明したことに始まる．以後りウマチ結 節による椎体破壊について, 七川菅, 菅野9), Heywood $^{3)}$, 桑原5) らが報告している. 1963 年, De $\mathrm{Seze}^{2)}$ は, RA の骨粗鬆症について 114 例の胸腰椎の レ線検討を行い, 84 例 $73 \%$ に骨粗鬆症を認めたと報告 している。この中で圧迫骨折は 8 例 $7 \%$ で，稀なもの だとし，Baggenstossが述べたような椎間板病変は 114 例中 1 例にしか認めず，極めて稀な所見だとも述 べている，RAに特徵的といわれる脊椎レ線変化とし ては, 椎体縁の Erosion, 骨棘を伴わない椎間腔狭小 化, 椎体のすべりなどが言われているが8)10)，われわれ の調查では，上記レ線変化は全て $7.4 \%$ と少なかった。 腰椎単純レ線だけではRAに特徵的所見を見いだす ことはむずかしく，今後 MRI などによる検索が必要 であると考えた。

RA 患者における骨粗鬆症の頻度は, 一般成人に比 べ高いとの松井ら ${ }^{7)}$ の報告があるが，われわれの調査 では, 骨粗鬆症は $69.1 \%$ に認め腰痛を主訴に当院を受 診した非 RA 女性患者 179 人中 105 人 $58.7 \%$ より高 かった。 また，年令別にみても井上ら ${ }^{4)}$ の 60 才代 35 $\%$, 70 才代 $47 \%$ という一般成人女性についての報告と 比較して明らかに高率であった。

RA において骨粗鬆症が存在することはよく知られ ており，その病因については，全身性の廃用，ステロ イド剤などの薬物による作用，加令変化，骨髄内炎症 性血管病変（Rheumatoid osteitis）などが関与してい るといわれているが，不明な点が多い. 今回，われわ れの調查で RA の骨粗鬆症およびこれに起因する圧 迫骨折は 60 才以上, Stage 3, 4, Class 2 以上に多く 認められた。したがって, RA 患者の骨粗鬆症は年令が 最も関係しており,さらにRA の活動性, 強い ADL 障 害による不動性が増し全身性廃用が加わると骨粗鬆症 が強くなると考えられた. RAにおける圧迫骨折は, $26.5 \%$ に認め松井らの $24 \%$, 桑原らの $35 \%$ と差はなか った。骨粗鬆症に由来する圧迫骨折は麻瘏を呈するも のは少ないといわれているが,われわれは 18 例中 4 例 に下肢不全麻痺を認めた ${ }^{6)}$. RA における椎体圧迫骨折 の中には, 脊椎周囲のなんらかの RA 病変が直接的,
間接的に影響して圧迫骨折および麻痺を起こすものが あると推察した．菅野，桑原らが指摘しているように， RA 患者の圧迫骨折に遭遇したときに，リウマチ結節 などの RA 病変に起因する比較的進行の急激な病変 もあることを念頭におき，注意深い経過観察をすべき だと考える。

\section{ま と め}

(1) RA患者68例の腰椎レ線について調査,検討した.

(2) 骨粗鬆症は, 68 例中 47 例 $69.1 \%$, 圧迫骨折は, 18 例 $26.5 \%$ に認められた。

(3) RA 患者の骨粗鬆症及びそれに起因する腰椎圧 迫骨折は, 60 才以上, Stage III, IV, Class 2 以上に多 く認められた。

(4) 圧迫骨折による下肢不全麻痺が 18 例中 4 例と 多くなんらかの RA 病変が関与しているものと考え られた.

\section{参 考 文 献}

1) Baggenstoss $\mathrm{AH}$, Bickel WH, Ward LE: Rheumatoid granulo-matous nodules as destructive lesions of vertebrae. J Bone Joint Surg 34-A : 601609, 1952.

2) DeSeze S, Debeyer N, Djian A: Radiological Study of the dorso-lumbar spine in rheumatoid arthritis. In : Proceedings of an international Symposium. Excerpta Medica ICS61, pp. 251-258, Amsterdam, 1963.

3) Heywood AWB, Meyers OL: Rheumatoid arthritis of the thoracic and lumbar spine. J Bone Joint Surg 68-B : 362-368, 1986.

4）井上哲郎, 山岸恒雄 : 大腿骨頸部骨折うと骨粗鬆症. 災害医学 $18: 175,1975$.

5）桑原 茂, 菅野卓郎：椎体にみられる RA 変化につ いて. 日関外誌 $2: 283-288,1983$.

6）前原東洋：吉永一春,福田稔朗ほか：骨粗鬆症に伴う 腰椎圧迫骨折による下肢不全麻痺の 3 例. 整形外科 4:177-184, 1989.

7）松井宣夫：リウマチの脊椎.リウマチ $17: 656$, 1977.

8）七川歓次：慢性関節リウマチにおける脊椎変化.リウ マチ病 I pp. 184-208, 永井書店, 1971 .

9）菅野卓郎，佐々木正，足立秀：椎体のリウマチについ て, 臨整外 $13: 720-727,1978$.

10) Tajima N, Kawano $K$, Takeuchi $H$, et al: Rheumatoid arthritis of the lumbar spine. A study of instability. JPN J Joint Surg 6: 531-540, 1987. 